\title{
THE SEEDLING OF CERATOZAMIA
}

\section{CONTRIBUTIONS FROM THE HULL BOTANICAL LABORATORY II5}

\author{
HELEN A. DORETY
}

\section{(WITH TWO FIGURES AND PLATES XII-XVI)}

The vascular anatomy of adult cycad stems is likely to be obscured by two sets of complications. One, called anomalous thickening, described by Von MoHL (I4) in $\mathrm{I}_{32} 2$ in species of Encephalartos, is limited to certain forms; the other, the phenomenon of girdling, was described by KARSTEN (5) in Zamia muricata Willd. in I856, and by Mettenius (8) in Cycas, Encephalartos, and Dioon in I860. Since then it has been found in the three other genera investigated. In the seedling these complications are either absent altogether or are just being initiated, hence the selection of juvenile forms is probably even more important in the anatomical study of cycads than in that of any of the other vascular plants. Anatomists have recognized this and have given us numerous descriptions, only the more pertinent of which need be cited here.

In I856 KARSTEN (5), in the work mentioned above, found that each of the cotyledons of Zamia receives only one bundle, which may branch; that the central cylinder is broken up by parenchymatous communication between pith and cortex; and that in older stems, with the increase in the number of cauline strands, there is a corresponding increase in the number of bundles entering the leaves, because every bundle of the central cylinder contributes a trace. He also observed the frequent anastomosing of the leaf traces reported by VoN MoHL, as well as the occurrence of girdling.

In I884 Bower (I) wrote a few descriptive notes on the seedling of Cycas Seemanni Al. Braun. He found the two cotyledons unequal in size and dissimilar in vascular anatomy. He says that while in some there is a median bundle which extends the whole length of the cotyledon without branching, in others there are two equal bundles near the center.

In I887 GREGG (4) reported anomalous thickenings in the root of this species.

203]

[Botanical Gazette, vol. $4^{6}$ 
In I896 WoRSDELL (I6) discovered them in the adult stem of Macrozamia Fraseri Miq., giving it an appearance which recalled to his mind the stem of the Medullosae.

In 1897 the same author (I7) gave the name "transfusion tissue" to certain short, scattered tracheids with reticulate markings on their transverse walls, found in lateral communication with the bundles in the green parts of some gymnosperms. He considers this tissue a "direct derivative of the centripetal xylem" in the vascular bundles of fossils. Later in the same year (I8) he recorded its occurrence in the cotyledons of Cycas revoluta Thunb. and in the leaf traces of Stangeria paradoxa T. Moore. He found that in each of the two cotyledons of Cycas revoluta, there are three collateral bundles, which may increase to five; that there may be some centrifugal wood near the base of the cotyledon, but none farther out; that the root may be tetrarch or triarch; that girdling had not yet begun in the young seedling he was investigating; and that anomalous thickenings were conspicuous. In Stangeria paradoxa, the two cotyledons have a common stalk, each is multifascicular, and the bundles are said to be concentric near the base. The root is triarch, changing to diarch near the tip. In the same paper, the two cotyledons of Macrozamia spiralis Miq. are said to be like those of Cycas revoluta.

The author calls attention to the absence of anomalous thickenings in this species of Macrozamia in contrast with the mature stem of $M$. Fraseri previously studied by him. In all three seedlings WORSDELL missed the transition from stem to root.

In 1898 the seedling of Bowenia spectabilis Hook. was described by Pearson (9). He says that each of the two cotyledons has four to seven bundles derived from one, and that these bundles are all collateral with normal orientation. He is emphatic as to the collateral nature of the bundles, even after having examined a preparation of WORSDELL's in which the latter considered them concentric. In the leaves the bundles are oriented normally, and the centripetal wood, scanty at the base, becomes more and more abundant farther up the petiole; but the centrifugal wood does not disappear even in the pinnae. The root is tetrach or pentarch, but may reduce to triarch. In the young material at his disposal, PEARson found no anomalous thickenings in the root, but they were discovered later in presumably 
older plants by WORSDELL (I9), who seized the occasion to emphasize the similarity to the Medullosae.

In 1904 MatTE (6) published his masterly thesis, which in the third part treats of the seedlings of Dioon edule Lindl., Cycas siamensis Miq., and Encephalartos Barteri Carruth. Of his two seedlings of Dioon edule one proved abnormal, one cotyledon being partly aborted. The cotyledonary bundles are mesarch near the base, but the protoxylem moves quickly outward, so that the bundles are exarch throughout most of their course. The axis is considered as an aggregation of leaf bases, and the girdling is explained as being due to intense intercalary growth produced under the influence of the developing leaf within. The four root poles are inserted upon the cotyledonary bundles, the median bundles furnishing insertion for two diagonally opposite poles, and each lateral trace uniting with its mate of the other cotyledon to furnish insertion for the other two poles. Mucilage canals are reported in the root, for the first time in a cycad. The root of Cycas siamensis is diarch; its two poles are inserted upon the median bundles of the cotyledons, the lateral bundles dying out in the cortex. Anomalous thickenings or cortical vascular strands are conspicuous; MATTE's demonstration that these are not abnormal, but merely remnants of an ancestral character, justifies his objection to the term "anomalous" used to describe them.

In Encephalartos the root is pentarch, and the cotyledonary bundles - a single, ringlike trace from each of the three cotyledonsfuse with the leaf traces at different levels before entering the central cylinder. This cylinder is polystelic, as in Medullosa anglica Scott. In considering this feature, MATTE indorses WorsDeLL's view that it helps to relate the Cycadales to ancient forms like Medullosa rather than to monostelic forms like Heterangium as Scotr suggests. He regards the root of cycads as a "new organ" inserted upon the lower extremity of the hypocotyl, and not merely an extension of that organ.

The main facts discovered by these investigations, and agreeing, so far as they relate to Dioon edule, Cycas, and Zamia, with unpublished studies made in this laboratory by LAND, THIESSEN, and others, may be classified as follows: 
Characteristic features.- Under this heading may be placed the occurrence of two cotyledons, the hypogean character of germination, the thick tap root, centripetal wood in the cotyledons and leaves, girdling, and numerous mucilage ducts.

Character upon which the seedlings may be divided into two groups.-This is the presence or absence of anomalous thickenings or cortical vascular strands. They occur in Cycas, Bowenia, and Encephalartos; they are said to be absent in Zamia, Dioon, Macrozamia, and Ceratozamia, though they were found in the mature stem of Macrozamia Fraseri by WoRSDELl. Microcycas remains to be reported upon.

Features peculiar to certain genera.-We may place here the single cotyledon reported for Ceratozamia, the three cotyledons of Encephalartos, concentric bundles in the base of the cotyledon of Stangeria, the polystele in the earliest formed part of the axis of Encephalartos, and mucilage ducts in the root of Dioon.

The present series of studies aims in the first part to add to the list a detailed account of Ceratozamia, Microcycas, Dioon spinulosum, and species of Zamia; and in the second part to extend the investigation to the conifers by examining some juveniles of each of the great groups. Podocarpus, Keteleeria, Cunninghamia, Pinus edule, $P$. Banksiana, and a few others, as well as the cycads mentioned, are well under way.

\section{Ceratozamia}

In I846 Brongniart (2) gave the generic and specific names to Ceratozamia mexicana, a "new cycad from Mexico." He described the adult forms and the ovulate and staminate strobili. In I870 WARMING (I5) reported the monocotyledonous character of the embryo. In I872 VAN Tieghem (I3) examined four seedlings and found a thick scale enclosed by the sheathing base of the single cotyledon, and, in turn, enclosing a hairy foliage leaf with circinate vernation. One of the four seedlings was suspected by him of having the rudiment of a second cotyledon. He describes the root after the xylem and phloem have reached their final position, and gives the number and derivation of the cotyledonary strands and early leaf traces; but in these respects, no two of the seedlings agree. A piece of mature stem, examined by Solms-Laubach (12) in I8go, was 
found to have a single cylinder, but peduncular strands occurred in the pith, an observation which was corroborated later by WORSDELL (I6). In the work previously mentioned (6) MATTE made a careful study of the ovulate cone and the mature leaf, with a few observations on younger leaves. He found terminal teeth on some of the pinnae of the younger plants, and at the bases of the petioles stipules with a bundle in each. He says that the meriphyte of the leaves has a modified $\boldsymbol{\Omega}$-shape in cross-section, with an anterior system, and shows that in this as well as in other cycad petioles the so-called fusions of the traces are often only approximations (accolements).

\section{MATERIAL AND METHODS}

The seedlings of Ceratozamia and Dioon spinulosum were grown from seeds provided by Professor Charles J. Chamberlain; the Microcycas seedlings were given to me by Professor Otis W. CaldWELL, and later some were grown from seeds secured by Professor Chamberlain. The Zamia seedlings were furnished by Dr. W. J. G. LAND.

Having in mind the danger of drawing conclusions from a few specimens, I have used freely the wealth of material at my disposal. The chief part of the investigation was made from material fixed in picro-acetic-alcohol, stained with safranin and anilin blue, and cut in serial sections. Figs. 21,22 , and 23 are diagrams of wax models constructed from serial sections.

\section{GENERAL DESCRIPTION OF EMBRYO AND SEEDLING}

The seeds of Ceratozamia are about $2 \cdot 5^{\mathrm{cm}}$ long and $\mathrm{I} \cdot 5^{\mathrm{cm}}$ thick, that is, about the same size as those of Dioon edule, and intermediate between Dioon spinulosum on the one hand and Zamia on the other. Like most cycad seeds, they are flattened on two or three sides by the pressure of growth within the cone, and it is not unimportant to remember that during the whole period of embryonal development - the longest known for a cycad-the seed lies upon whatever side it happens to fall. The single cotyledon begins to be differentiated in November, and early in December its appearance is like that represented in fig. $I$. Later it begins to surround the axis (fig. 2), and finally the two edges meet (fig. 3). In these early stages, the coleorhiza is proportionally long; but later elongation of the coty- 
ledons forces the base of the embryo backward, so that both coleorhiza and suspensor are crushed little by little to a flat, brown disk (figs. 4, 5). Further elongation forces the base of the embryo through the softer, micropylar portion of the seed coat; figs. $6,7,8$ show this and the two succeeding stages. In fig. 7 the base of the cotyledon is curved downward, and the plumule is seen issuing from between its opened edges; and it may be observed that this method of development has thrown the first leaf out of alignment. The edges close in again, and remain adhering the full length of the cotyledon (fig. I3). The tip is sometimes lobed (figs. I4, I5).

The cotyledon always develops on the lower side of the embryo as the seed lies during germination. In seedlings which were turned after the cotyledon had begun to develop, the plumule has not succeeded after a year in emerging from underneath the cotyledonary sheath with which it is hampered.

Fig. 8 shows the appearance of the tardy root, which has made its way through the brown cap formed from the remains of the disorganized coleorhiza and suspensor. When the root pierces the soil, the starch is transferred to it from the endosperm, and the root thickens into a tap root. By its further penetration into the soil, it often draws the upper portion further down, imbedding the seed, and possibly giving to the first series of lateral roots their initial upward slant. The lateral roots almost always appear in threes, whether the root be tetrarch or triarch. Fig. 9 represents a seedling toward the close of this period of its activity. The extreme shortness of the hypocotyl may be conjectured from the small distance between the base of the cotyledon and the insertion of the first whorl of lateral roots. The plumule is composed in this case of two brownish, hairy scales, enclosing a foliage leaf with circinate vernation (fig. Io). Each scale is terminated by a sharp, curved point. The number of scale leaves varies in different seedlings; some have only one, and in in some few observed the first organ was a perfect foliage leaf. The base of both scale leaf and foliage leaf is furnished with broad, winglike expansions which enclose the next leaf. The petiole of the first leaves reaches a length of $\mathrm{I}^{-20^{\mathrm{cm}}}$, and bears one or two pairs of pinnae inserted near the adaxial face. Between the two terminal pinnae there is a tiny, sharp spine, which has its counterpart in the 
apical point of the scale leaves. At irregular intervals along the petiole are other, even smaller points. The first leaves are opposite, but the later ones assume the spiral phyllotaxy represented in fig. I2.

\section{ANATOMY}

As was above noted, the edges of the cotyledon close in after the exit of the.plumule, the two halves of the adaxial face meeting in a plane represented by the line $a d$ in fig. I3. Three bundles enter the cotyledon from the vascular plate, and each dichotomizes again and again (fig. I 6 ), the median one being no more a "double" bundle than any of the others. The number of traces may be increased to fifteen toward the upper portion, but is gradually reduced again toward the tip, some bundles approximating in pairs, others dying out. Those in the lobes disappear lower down than the others (fig. I5). The bundles are collateral throughout the cotyledon, and their orientation is normal, as seen in figs. I3, I4, I5, where the xylem faces the line $a d$. The wood is mesarch (fig. I7), with the protoxylem gradually moving out toward the phloem as it ascends. In the upper portion centrifugal elements are wanting, that is the wood is exarch (fig. I8). The vascular system of the cotyledon is differentiated relatively early in the development of the seedling. In that from which fig. Ig was drawn, in which no root has yet appeared, the vessels are fully matured. WoRSDELL's transfusion tissue was frequently observed in direct continuation with the centripetal xylem (fig. $18, \mathrm{tr}$ ).

Mucilage canals are numerous in the lower part, and seem to bear no definite relation to the strands (figs. 30, 3I); farther up they usually number one more than the strands and alternate with them; higher still they die out irregularly; in some cotyledons they are absent altogether.

The vascular plate of the hypocotyl axis is irregularly four-sided as seen in cross-section; all the xylem is in the center, sometimes in a solid mass, sometimes interspersed with pith cells. The protoxylem points are clearly distinguishable. In the plant from which fig. 20 was drawn, the protostelic condition persisted through a vertical distance of $1.6^{\mathrm{mm}}$. Above this the pith cells occupy the central region, so that a siphonostele replaces the protostele (fig. 28). About 
$\mathrm{I}^{\mathrm{mm}}$ above the upper terminus of the protostele, the xylem is grouped sometimes in four conspicuous mesarch lobes, but oftener in three prominent ones and a fourth weaker one (D, fig. 29). From this weaker lobe a very small strand passes out ( $D$, figs. $2 I-24,26,30)$, and in some cases it branches, but is lost in the cortex. From the lobe diametrically opposite, the median strand of the cotyledon ( $C$, figs. 2I, 24, 25, 29, 30) enters that organ; and from each of the other two angles or lobes a strand passes out $(A, B)$ and branches, one member in each case bending tangentially $\left(b, b^{\prime}\right)$ to form the lateral trace of the cotyledon, the other, a very small strand $\left(a, a^{\prime}\right)$, either fusing with the leaf traces or dying out in the cortex. This cotyledonary node is represented in cross-section in the diagram (fig. 24).

Comparison with the same node in Zamia, Cycas, Dioon edule, and Microcycas suggested that the smaller bundles $\left(D, a, a^{\prime}\right)$ were the mates of the larger ones on the side of the cotyledon $\left(C, b, b^{\prime}\right)$, and that the second cotyledon was suppressed. The cause of the suppression was indicated by the long-continued one-sided presentation to gravity during germination, and the fact that the cotyledon is always on the under side. It was with the intention of testing these surmises that the experimental work already recorded (3) was undertaken. Fig. 25 represents the cotyledonary node in Ceratozamia embryos developed on the clinostat, and fig. I $3 a$ a transverse section of their cotyledons.

Although the stem contains several layers of extrafascicular cambium ( $c b$, fig. $3^{2}$ ), I have not been able to find in two-year-old plants any anomalous thickenings except the solitary bundle (fig. 33) whose position in the base of the cotyledon is indicated in fig. 30 at z. This bundle has its origin in a small group of cells $\left(c b^{\prime \prime}\right.$, fig. 32$)$ in the outermost layer of cambium. It is about $0.4 \mathrm{~mm}$ long and approximately vertical. Its tracheids have only spiral thickenings.

The foliar bundles $(f b)$ may occur in four groups alternating with the cotyledonary bundles (figs. 2I-23, 26, 30); but oftener there are only three groups, because of the fusion of two of them or the entire elimin ition of one, on the side of the suppressed cotyledon, when the main bundle $(D)$ is slight or entirely wanting (fig. 26). At first they are all vertical; higher up they branch, and a strand from each group 
is sent to the first leaf (fig. 22). As previously noted, this organ, whether scale leaf or foliage leaf, is displaced laterally by the peculiarities of its development. All the traces which enter it are likewise distorted, giving rise to a pseudogirdling condition which is apparent in very young seedlings (figs. 22, 27, 3I). The two traces which enter from the groups nearest the leaf $\left(e, e^{\prime}\right)$ take first a radial, and then a tangential course to reach a position in the middle of the leaf (figs. 22, 3I), showing on the way a tendency to branch. The traces $\left(d, d^{\prime}\right)$ supplied from the groups farther away take a tangential course, each giving off vertical branches, which in turn branch again. The remaining traces of the original four foliar bundles ascend vertically ( $f i g .25)$, and branch and anastomose freely. Only a limited number, in most cases four or five, remain ( $f b$, figs. 24, 3I). Before reaching the leaf base, each of these divides, one member entering it ( $t$, fig. 23), the other, which remains small, being directed toward the growing point of the stem (u, figs. 23, 27). Fig. 23 represents the branching and anastomosing of these strands. It should be noted that the vertical scale of the three diagrams (figs. $2 I-23)$ is magnified considerably.
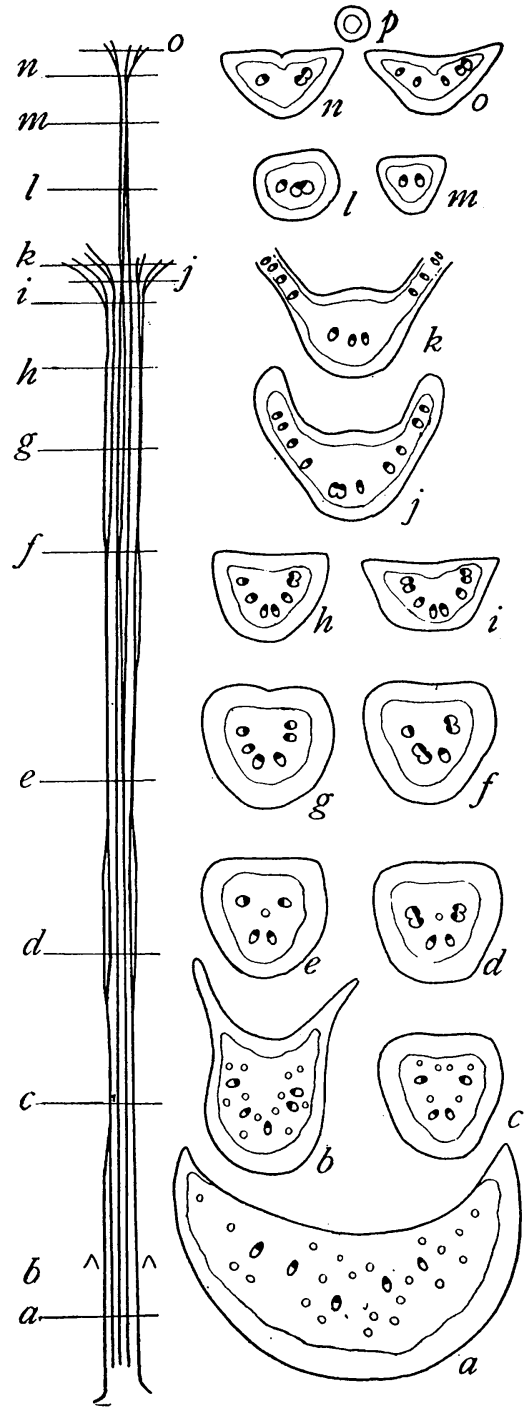

FIG. I.-Study of foliage leaf from base (a) to apex $(p)$; for explanation see text.

In the younger stages there is no attempt at girdling on the part of the leaf traces, except that which has been referred to in the first 
leaf as pseudo-girdling, whose cause is to be sought in the accident of its development. When the inner face of a leaf encloses a mass whose diameter is less than $3^{\mathrm{mm}}$ (fourth leaf in fig. I2), the vascular bundles of that leaf are all vertical; but when the enclosed mass, by its enormous radial growth, has reached a diameter of $5^{-8 \mathrm{~mm}}$ and comprises two or more developing leaves (second leaf in fig. I2) the base of the enclosing leaf enlarges its inner face accordingly. The first stage in the enlargement consists in an increase in the number of cells, but the second in a horizontal elongation of these (text fig. I). While this is going on the older part of the central vascular cylinder is also increasing its diameter, separating farther and farther the original positions of the bundles of the leaf. As a result, the marginal traces gradually elongate as they are drawn more and more from the vertical position, and their upper parts stretch outward in the direction which the leaf takes. These facts have been observed repeatedly; whether they are an adequate solution of the problem of the cause of girdling, as MatTe thinks, I am unable to say.

In seedlings with three or four leaves, the stem bundles ( $u, f i g .19)$ branch repeatedly, and many of the branches reunite to form a small number of traces. Each of the remaining ones now forks once, the larger member in each instance going to the leaf as before, the smaller one continuing in the axis. Thus, even at this early stage, there is present the sympodial stem described by Miss SMITH (II) for older plants.

The number of strands entering successive leaves was seen to increase, sometimes with great regularity. In the plant whose dissection is represented in figs. $I I$ and $I 2$, the number of traces was increased by one in each successive leaf, from the cotyledon with three, to the fourth leaf with seven; but the increment was not so constant in all the plants observed.

Within the leaf base and in the petiole, the bundles branch and anastomose freely. There is no real $\Omega$ in these first leaves; the bundles are arranged simply in an open arch. Text fig. 2 is a study of a foliage leaf which was the second lateral organ of the plumule, that is, it was preceded by only one scale leaf. The scale leaf had four bundles; this leaf has five $(a, b)$; but just above the stipules the number is reduced to four by the approximation of two of them $(c)$. 
Other changes occur as the meriphyte ascends the petiole $(c, d)$. Just below the first pair of pinnae the branching is rapid, and at the level where the blade is seen exteriorly to separate from the petiole, there are four strands provided for it $(j)$. In the rachis another approximation takes place $(l)$, and the number of bundles is reduced to two $(m)$. Each enters a pinna and branches continuously $(n, o)$. The growing point terminating the rachis has no vascular trace in this leaf, in this respect agreeing with the young leaf represented in fig. Ioa. As the plant increases in age, the meristem of this point retains its activity longer, producing a greater number of pinnae, as in the seed plants.

The wood in all the leaf traces is endarch in the central cylinder (fig. 26), but it soon becomesmesarch, with the protoxylem moving outward by almost imperceptible degrees. It never reaches the exarch condition, however; even in the tips of the pinnae there are always two or three elements of centrifugal wood. Here and there may be seen a few

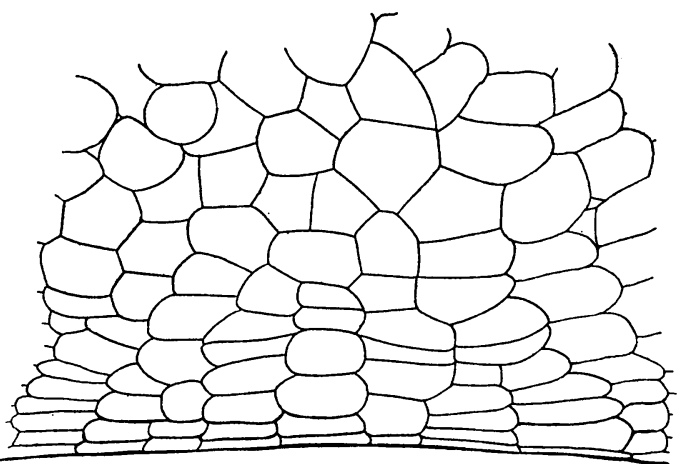

FIG. 2.-Cross-section of flattened cells from inner face of petiole near the base.

elements of transfusion tissue.

Mucilage canals are numerous in the leaf bases (figs. 30, 3I), but they have no more definite arrangement there than in the base of the cotyledon. Throughout the region of the stipules there is a gradual decrease in number, which is not altogether due to fusing. Toward the upper levels of this region they are sometimes arranged in two series, an adaxial row and an abaxial one, with a definite relation to the bundles (text fig. $2 b$ ). About $\mathrm{I}^{\mathrm{cm}}$ above the base, there is left only one centrally located canal $(d)$, which persists for half the length of the petiole $(e)$.

The bases of the leaves as well as of the cotyledons are covered by a thick layer of cork. As was seen externally, the hypocotyl is extremely 
short, the transition from stem to root taking place in an almost horizontal plane (fig. 3o). In the absence of cauline bundles, the root poles are inserted upon the cotyledonary strands $(A, B, C, D$, figs. $34,35)$. There is no rotation of the protoxylem, but the phloem and metaxylem separate opposite the protoxylem groups ( $B n, C n, f i g$. 36), the cambium proliferating to fill the breach in the metaxylem, and the cortex invading the space left vacant by the phloem. The resulting halves swing, the one to the right, the other to the left, giving the appearance of a double fan of phloem and metaxylem connected by a single group of protoxylem. The right half of the phloem of one pole joins the left half of that of the next, and the cambium layer is thus curved inward ( $c b$, figs. $\left.37,3^{8}\right)$. One result of this complicated process is that the entire xylem system of the root is bordered peripherally by cambium.

The medulla throughout the root is extremely meristematic, and its activity sometimes results in a displacement of one or more of the protoxylem groups, giving an unsymmetrical appearance in crosssection. This activity is indicated by the thin walls (o, fig. $3^{8}$ ) showing recent division.

In all the plants I have investigated, the number of poles remains constant throughout any given root. This number may be three or four, depending seemingly upon the degree of development attained by the median bundle of the aborted cotyledon. Figs. 26 and 34 will serve to illustrate this point. They represent the same level in two different plants. In the former the median bundle $(D)$ was very weak, and there were but three root poles; in the latter this bundle was well developed and the root was tetrarch.

Fig. 39 represents the condition of the root tip in the region of the differentiation of protoxylem. The connective tissue is clearly defined, but there is no xylem plate connecting the poles. Examination of longitudinal sections of the root tip furnishes nothing that could be added to the description of REINKe (Io). One initial group produces plerome, another periblem. There is no calyptrogen or dermatogen, but the outermost layers of the periblem become loosened at the tip and form the root cap $(k, f i g .42)$.

There is no distinct endodermis, and the pericycle is severallayered, making it impossible to distinguish with absolute cer- 
tainty any line of demarkation between phloeoterma and stelar tissue.

There are no anomalous thickenings in the roots of plants two years old.

In general, mucilage ducts extend but a slight distance into the root, usually about $8^{\mathrm{mm}}$, but in one specimen they were beginning to be formed in the plerome, immediately behind the region of its differentiation ( $m d, f i g .42)$.

The lateral roots are diarch. Fig. 40 represents a transverse section of a secondary root and the exit of a tertiary one. The uppermost lateral roots become ageotropic at a very early stage, and show symptoms of bacterial infection; and in some of the two-year-old plants, these roots present the characteristic "coralloid" appearance indicative of algal infection.

The root, as was seen above, is late in developing. Fig. 27 represents the position and form of the meristematic plate, which has given rise to stem above, but is yet inactive below. Fig. Ig shows the beginning of the activity which produces the root; the central portion of the active region in this figure is sketched in greater detail in fig. $4 I$. In the stage represented in fig. 42 , the root cap is developed and the plerome and periblem initial groups are easily distinguishable, but the plerome has not yet differentiated any xylem elements.

While in older seedlings the vascular systems of stem and root seem to be continuous, one sometimes finds sections which indicate a certain amount of interruption. Such a case is shown in fig. $43 .^{\mathrm{x}}$

\section{Discussion}

The result of the experimental work on Ceratozamia places this genus in line with the other cycads with reference to the dicotyledonous

r When this investigation was completed, MATte (7) published a preliminary note on the same subject. He says that the petiolary bundles have the $\Omega$ arrangement, that there is an anterior fascicular system in the region of insertion of the rachis, and that the pinna has terminal teeth. These features do not appear in any of my seedlings. Speaking of the root, he says it is tetrarch, and that he has observed a progressive reduction of poles, to three and even to two. As I have observed, no reduction occurred in the roots of any of the seedlings I sectioned, and the root is triarch as often as it is tetrarch. He has also found the abnormal thickenings strongly developed; but he does not give the age of the seedlings which manifest them. 
character. The proof of the abortion of the second cotyledon and the discovery of the manner in which that abortion was brought about naturally revive the question of the monocotyledonous nature of certain dicotyledons. It is possible that in some cases this condition may be caused by the same factor which produces it in the embryo of Ceratozamia, but this is not so in all cases; the experimental work now in progress upon these forms shows that other factors are involved.

The lobing at the tip of the cotyledon is suggestive of a primitive condition, which will be discussed in connection with Dioon spinulosum.

It would be interesting to compare the cotyledonary node in all cycads, in order to determine whether they are modifications of the same type or whether there are different types; but it is a matter of regret that all investigators have not considered it of sufficient importance. MATTE has described it fully for Dioon edule and Cycas siamensis. The latter is clearly a modification of the type which may be represented by the former. The present paper shows that Ceratozamia conforms to this type, and it may be in place here to say that Microcycas and the species of Zamia I am investigating are the same. WoRsDell's Cycas revoluta and Macrozamia spiralis are doubtless similar. Encephalartos Barteri according to MatTE's description, Zamia muricata according to KARSTEN's, and Bowenia spectabilis according to PeARson's seem to differ from this type, in receiving only one bundle from the central cylinder; but there are two facts which conspire to make us consider that the seedling of Encephalartos described by MATTE was an unusual one: the presence of three cotyledons, and the union of the cotyledonary strands with the central cylinder at different levels.

That cycads, especially such fernlike ones as Stangeria and Bowenia, should be found to have an occasional concentric bundle is only to be expected from the nature of their fern origin. WorsDELL's announcement, then, of such bundles in the base of the cotyledon of Stangeria was not a surprise, even though his drawings were not convincing. But the emphatic statement of PEarson that he could not be convinced of it in WorsDell's preparation of Bowenia raises the doubt whether he would have recognized it in Stan- 
geria. Of course the whole question resolves itself into the possibility of determining phloem in the absence of sieve plates.

In the feature of anomalous thickenings, as in so many other features, Ceratozamia appears to hold an intermediate position. The extrafascicular cambium is clear and distinct, yet in plants with two scale leaves, two expanded foliage leaves, and two or three leaves developing, the secondary fascicular systems are entirely wanting. The failure or delay of this cambium to function indicates that it is a vestigial character. I have seen it in Zamia as clear and distinct, though not so abundant, as in Ceratozamia.

There seems to be great variation in the number of root poles throughout the whole group of cycads and even in individual roots. This variation, taken in conjunction with the fact that in Ceratozamia the number depends upon the degree of development of the median bundle of the aborted cotyledon, indicates that this character is not to be depended upon as a phylogenetic one.

\section{Summary}

I. Ceratozamia is dicotyledonous, the second cotyledon being aborted by gravity.

2. The cotyledon is often lobed at the tip. It is multifascicular, and all the bundles are derived from three. The wood is mesarch at the base and exarch in the upper portion. Mucilage ducts usually alternate with the bundles.

3. The leaf traces are at first vertical; girdling follows upon increase in radial growth of the enclosed leaves and stem apex. The wood of the leaf traces is endarch in the central cylinder, but becomes mesarch in the leaf base and remains so to the tips of the pinnae.

4. The scale leaves are aborted foliage leaves.

5. The first-formed portion of the central vascular cylinder may be a protostele.

6. The stem is a sympodium.

7. There are several layers of extrafascicular cambium, but in seedlings two years old only the slightest trace of anomalous thickening.

8. The root is a delayed organ, and its four poles are inserted upon the cotyledonary bundles. 
9. The entire xylem system of the root is bordered peripherally by cambium.

Grateful acknowledgments are due to Professor JoHN M. CoulTER and Dr. W. J. G. LAND, under whose direction the investigation was conducted, and to Professor Charles J. Chamberlain for abundance of material.

The University of Chicago

\section{LITERATURE CITED}

I. Bower, F. O., On the comparative morphology of the leaf in vascular cryp togams and gymnosperms. Phil. Trans. Roy. Soc. I75:583. I884.

2. Brongniart, A., Note sur un nouveau genre de Cycadées du Mexique. Ann. Sci. Nat. Bot. III. 5:5. I846.

3. Dorety, Helen A., The embryo of Ceratozamia: a physiological study. Bот. Gazette 45:412. I908.

4. Gregg, W. H., Anomalous thickening in the roots of Cycas Seemanni Al. Braun. Annals of Botany $1: 63$. I887.

5. KaRsten, H., Organographische Betrachtungen der Zamia muricata Willd. Abh. der Berlin Akad. 193. I856.

6. Matte, Henri, Recherches sur l'appareil libéro-ligneux des Cycadacées. Caen. IgO4.

7. — - Note préliminaire sur des germinations de Cycadackes. Rennes. 1907.

8. Mettenius, G., Beiträge zur Anatomie der Cycadeen. Abh. Königl. Sächs. Gesells. Wiss. 7:565. 1860.

9. Pearson, H. W., Anatomy of the seedling of Bowenia spectabilis. Annals of Botany 12:475. I898.

ro. Reinke, J., Beiträge zur Kenntniss der Gymnospermen Wurzel. Morph. Abh. Leipz. I873. (Reviewed in Just's Bot. Jahrb. I:205. 1873.)

II. Smith, Frances Grace, Morphology of the trunk and development of the microsporangium of cycads. BоT. GAZETTE 43:187. I907.

12. Solms-Laubach, H. Graf zu, Die Sprossfolge der Stangeria und der übrigen Cycadeen. Bot. Zeit. 48: I77. I89o.

I3. Van Tieghem, Рн., Symetrie de structure des plantes. Ann. Sci. Nat. Bot. V. 13:204. I873.

I4. Von MoHL, H., Ueber den Bau der Cycadeen Stammes und sein Verhältniss $\mathrm{zu}$ dem Stammes der Coniferen und Baumfarnen. Abh. Königl. Akad. Münch. I832. Vermischte Schriften I95. I845.

I5. Warming, E., Ein Paar nachträgliche Notizen über die Entwickelung der Cycadeen. Bot. Zeit. 36:737. 1878.

r6. WorsDelL, W. C., The anatomy of the stem of Macrozamia compared with that of the other genera of Cycadeae. Annals of Botany ro:60r. 1896. 
I7. - On the origin of transfusion tissue in the leaves of gymnospermous plants. Jour. Linn. Soc. 33: 118. 1897.

18. - Comparative anatomy of the Cycadaceae. Jour. Linn. Soc. 33:437. I898.

I9. - The anatomical structure of Bowenia spectabilis Hook. Annals of Botany I4: I59. I900.

\section{EXPLANATION OF PLATES XII-XVI}

All the drawings except figs. 6-II, I6, 2I-25 were made with the aid of a camera lucida. The abbreviations used are as follows: $A, B, C, D$, the four main cotyledonary bundles; $A n, B n, C n, D n$, the corresponding root poles; $C$, median bundle of developed cotyledon; $D$, median bundle of aborted one; $a, a^{\prime}$, lateral bundles of aborted cotyledon; $b, b^{\prime}$, lateral bundles of developed one; $a d$, adaxial face of cotyledon; $c$, cotyledon; $c b$, cambium; $c b^{\prime}, c b^{\prime \prime}$, extrafascicular cambium; $c l$, coleorhiza; $c t$, connective tissue of root; $c x$, cortex; $c f x$, centrifugal xylem; $c p x$, centripetal xylem; $d, d^{\prime}$, lateral traces of first leaf; $e, e^{\prime}$, middle traces of same; $f$, foliar bundles; $f^{\mathrm{r}}, f^{2}, f^{3}, f^{4}$, four principal groups of foliar bundles; $g$, cotyledonary trace; $h$, vascular system of hypocotyl; $i$, vascular system of root; imd, initiation of mucilage duct; $j$, sclerenchyma; $k$, root cap; $l$, leaf; $m$, meristematic plate; $m d$, mucilage duct; $n$, medulla; $o$, indices of radial cell division in medulla; $p$, plumule; $p h$, phloem; $p p h$, protophloem; $p x$, protoxylem; $p x^{\prime}$, rupture of tissues caused by protoxylem; $q$, plerome; $r$, root; $s$, suspensor; $t$, leaf trace; $t r$, transfusion tissue; $u$, stem bundles; $v$, periblem; $w$, stipules; $x$, xylem; $y$, cork; $z$, anomalous thickening.

FIGs. I-5.-Stages in intraseminal development showing single lateral cotyledon and gradual enlargement of its base to encompass axis. $\times_{5}$.

FIg. 6.- Rupture of micropylar end of seed coat and protrusion of base of embryo. $\times \frac{1}{2}$.

FIG. 7.-Bending of base of embryo and exit of plumule. $\quad \times \frac{1}{2}$.

Fig. 8. -Appearance of root. $\times \frac{1}{2}$.

Figs. 9, ro.- Young seedlings. $\quad \times \frac{1}{2}$.

Fig. Ioa.-Longitudinal section through tip of unfolding leaf. $\times_{5}$.

FIG. II.-Dissection of aerial portion of two-year-old seedling. Nat. size.

Fig. I2.-Diagram showing spiral phyllotaxy of later leaves. Nat. size.

FIg. I3.-Transverse section of cotyledon. $\times 8$.

FIG. I 3 a.-Transverse section of cotyledons of embryo developed on clinostat. $\times 8$.

FIG. I4.-Transverse section of upper portion of cotyledon showing tendency to lobe. $\times 8$.

FIG. 15.-Transverse section of same cotyledon nearer tip. $\quad \times 8$.

Fig. I6.-Diagram to show venation of cotyledon.

Fig. I7.-Mesarch bundle from lower portion of cotyledon. $\quad \times_{380}$.

FIG. 18. - Exarch bundle from the middle region of cotyledon. $\quad \times_{3} 80$. 
Fig. I9.- Longitudinal section of lower part of embryo emerging from seed. $\times 8$.

Fig. 20. - Transverse section of the vascular plate of hypocotyl. $X_{225}$.

FIG. 21.-Diagram representing rise of cotyledonary bundles from vascular plate.

FIG. 22.-Diagram showing origin and course of first leaf traces.

FIG. 23.-Diagram showing origin and behavior of traces of second leaf.

Fig. 24.- Horizontal diagram of cotyledonary node.

FIG. 25.-Same node in plants developed on clinostat.

Fig. 26.-Transverse section slightly above cotyledonary node showing the four main cotyledonary bundles and the three groups of foliar bundles. $\times 60$.

Fig. 27.-Longitudinal section of embryo somewhat less developed than the one represented in fig. Ig. $\times$ Io.

Fig. 28.-Transverse section of stele of hypocotyl $2^{\mathrm{mm}}$ above the section represented in fig. 2o. $\times 225$.

Fig. 29. - Transverse section of stele of hypocotyl immediately below cotyledonary node. $\times 225$.

FIG. 30.-Transverse section of plant with median bundle of aborted cotyledon fairly well developed. Same level as fig. 26. $\quad \times 8$.

FIG. $3^{\text {I. }}$-Section of same plant $\mathrm{I} 40 \mu$ above that represented in fig. $30 . \quad \times 8$.

Fig. 32.-Detail of portion of axis $0.2^{\mathrm{mm}}$ below fig. 30 , between the cotyledonary bundle $B$ and the phellogen; shows group of cambium cells which gave rise to anomalous strand $z$. $\times 75$.

Fig. 33.-Transverse section of the anomalous strand represented in base of cotyledon in fig. $30 . \quad \times_{\mathrm{I}} 35$.

FIG. 34.-Cotyledonary node of plant with median bundle of aborted cotyledon well developed. $X_{I_{5}}$.

Fig. 35.-Stele of hypocotyl $0.36^{\mathrm{mm}}$ below fig. 34; xylem and phloem collected in ring. $\times \mathrm{I}_{5} \mathrm{O}$.

Fig. 36.-Section of stele of same plant 0. $16^{\mathrm{mm}}$ below fig. 35; shows breaking apart of phloem opposite the protoxylem. $\times \mathrm{I}_{5} \mathrm{O}$.

FIG. 37.-Same, $0.2^{\mathrm{mm}}$ below the previous section; separation of metaxylem. $\times$ r5o.

Fig. 38.-Section of root stele between the third and fourth whorls of lateral roots. $\times \mathrm{I} 79$.

Fig. 39.-Section of stele near root tip at beginning of differentiation of xylem. $\times 225$.

FIG. 40.-Transverse section of stele of lateral root showing exit of a tertiary root. $\times 225$.

Fig. 4I.-Longitudinal section of seedling showing beginning of root formation. $\times$ ro.

Fig. 42.-Detail of beginning of root formation. $\times 60$.

Fig. 43.-Detail showing interruption between vascular tissues of hypocotyl and root. $\times \mathrm{I} 20$. 


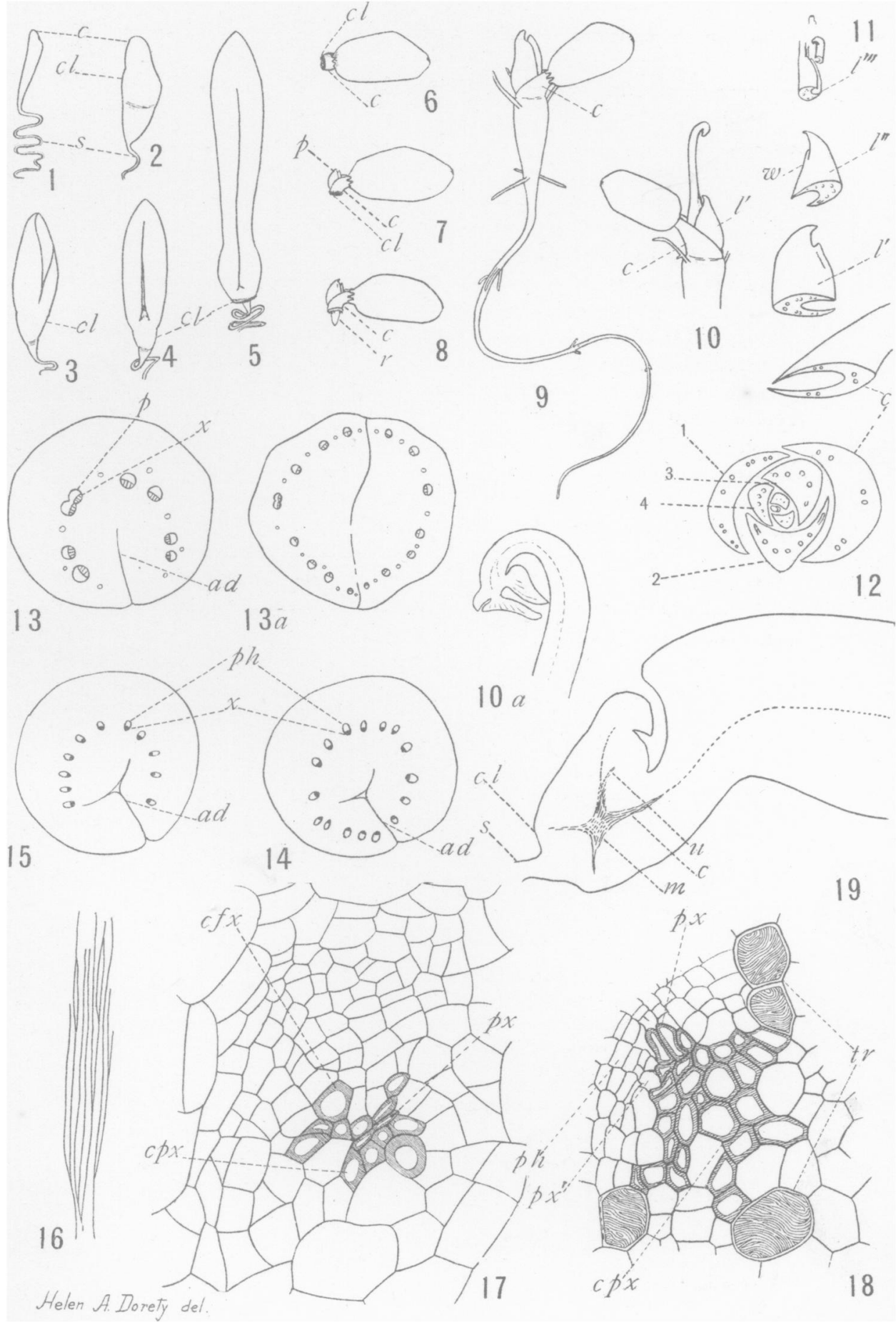

DORETY ON GERATOZAMIA

This content downloaded from 080.082.077.083 on February 01, 2018 14:00:02 PM

All use subject to University of Chicago Press Terms and Conditions (http://www.journals.uchicago.edu/t-and-c). 


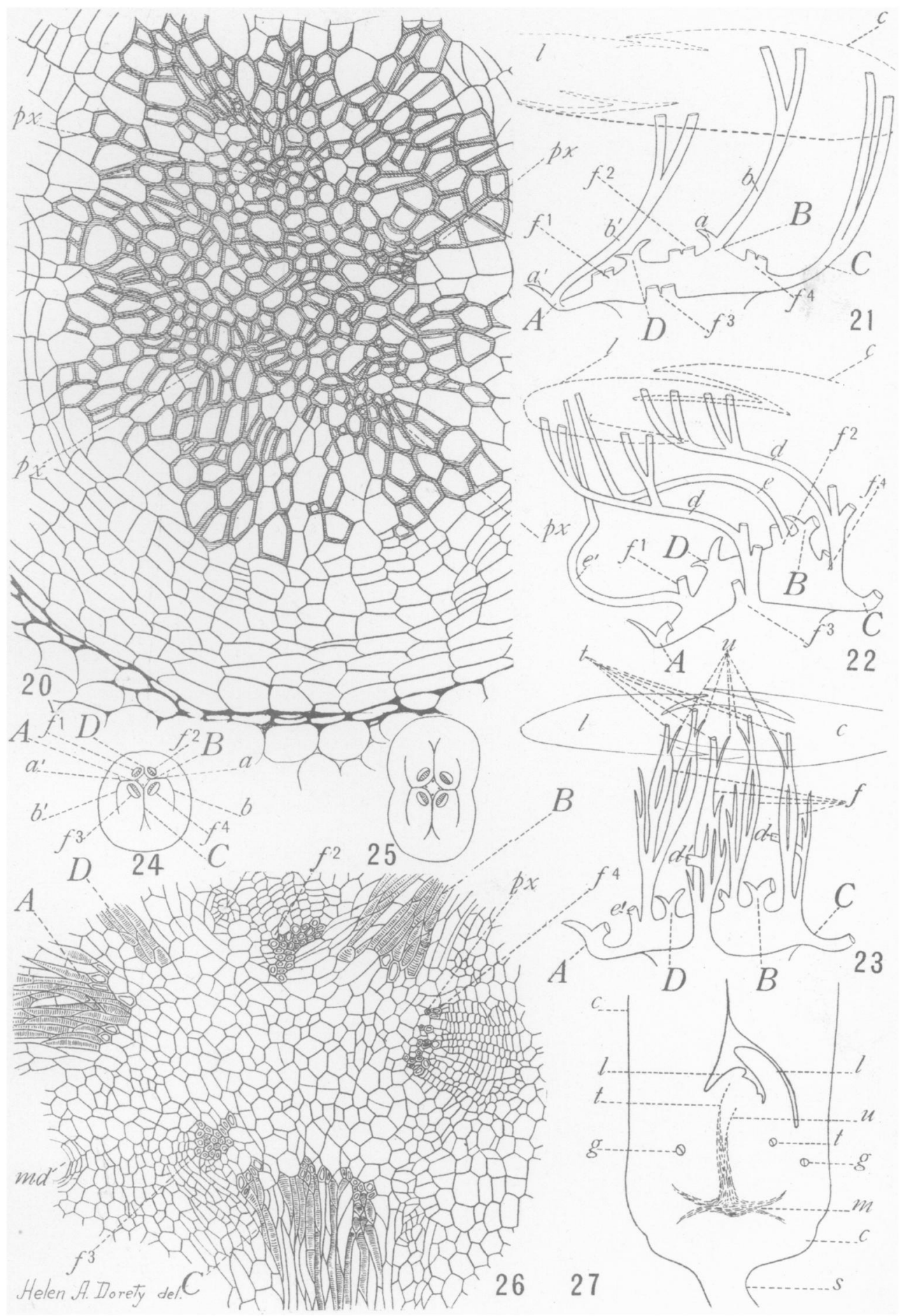

DORETY ON GFIRATOZAMIA

This content downloaded from 080.082.077.083 on February 01, 2018 14:00:02 PM

All use subject to University of Chicago Press Terms and Conditions (http://www.journals.uchicago.edu/t-and-c). 


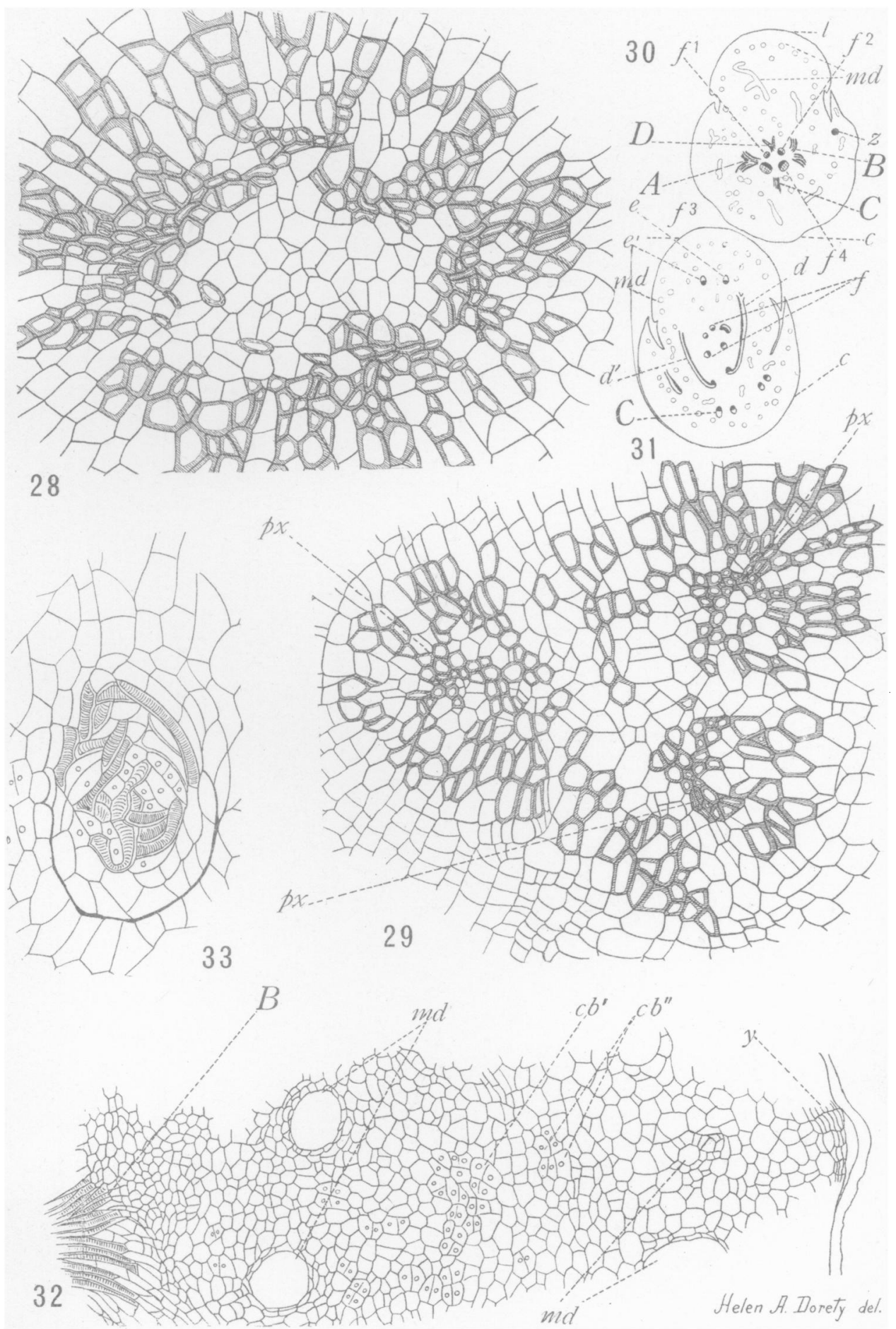

\section{DORETY ON GERATOZAMIA}

This content downloaded from 080.082.077.083 on February 01, 2018 14:00:02 PM All use subject to University of Chicago Press Terms and Conditions (http://www.journals.uchicago.edu/t-and-c). 

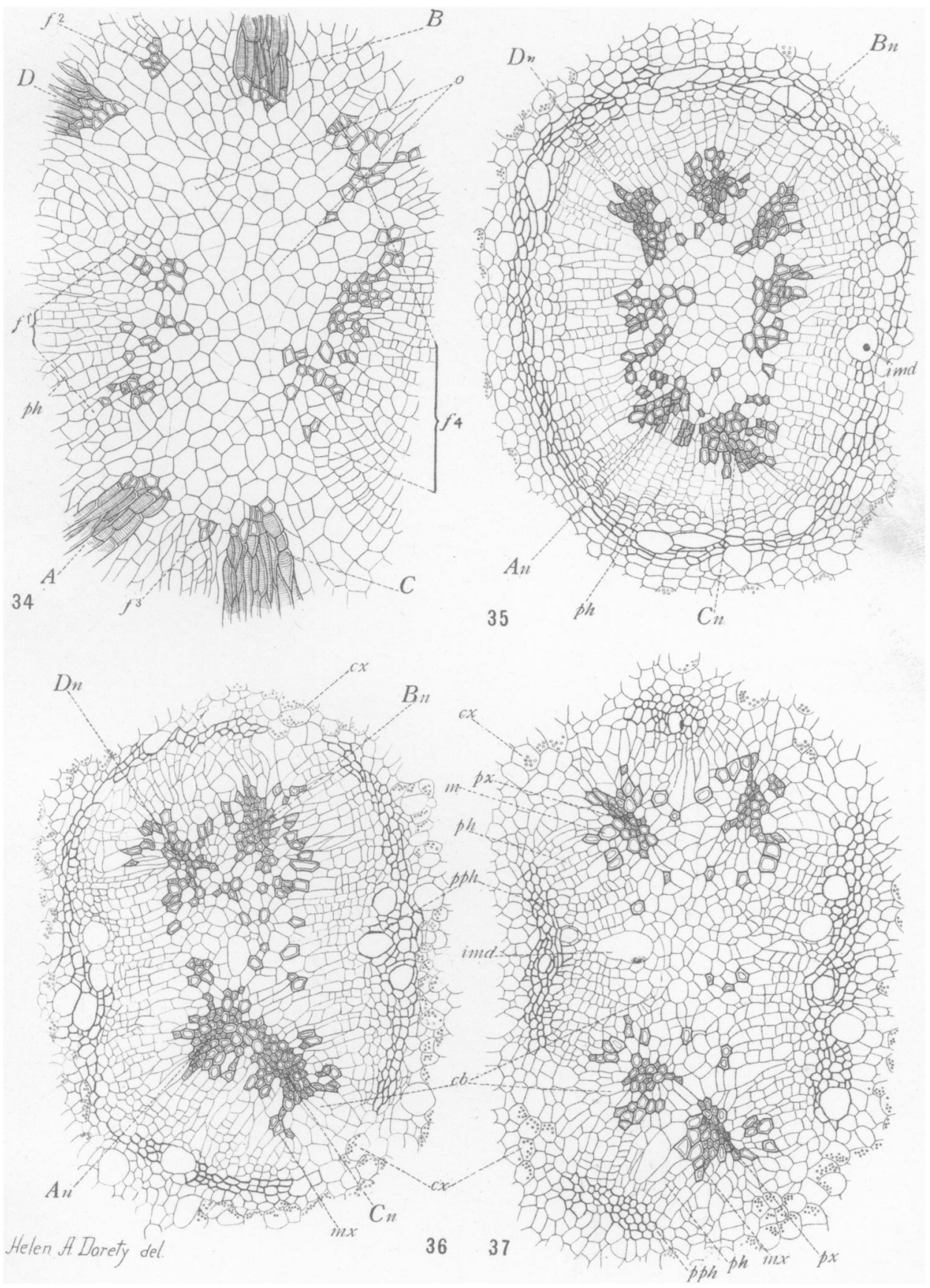

DORETY ONGERATOZAMIA

This content downloaded from 080.082.077.083 on February 01, 2018 14:00:02 PM

All use subject to University of Chicago Press Terms and Conditions (http://www.journals.uchicago.edu/t-and-c). 


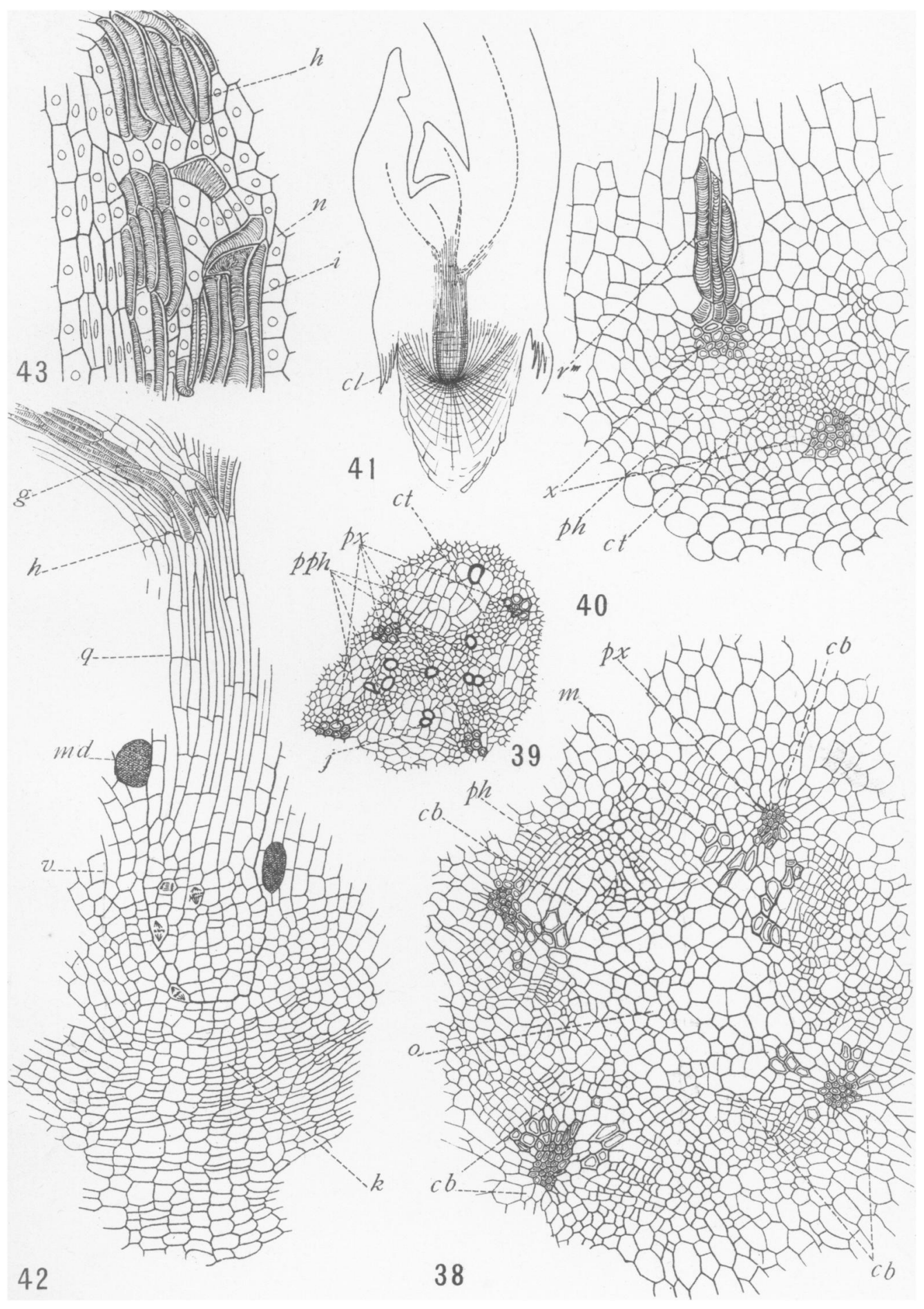

DORETY ON GERATOZAMIA

This content downloaded from 080.082.077.083 on February 01, 2018 14:00:02 PM

All use subject to University of Chicago Press Terms and Conditions (http://www.journals.uchicago.edu/t-and-c). 